\title{
Kompetencje i ich profesjonalizacja jako czynnik rozwoju współczesnego człowieka
}

\begin{abstract}
Streszczenie
Współczesny człowiek poszerza i wykorzystuje indywidualne możliwości do aktualizowania, pogłębiania oraz wzbogacania potencjału wiedzy, umiejętności i kompetencji, by przystosować się do zmieniającej się społecznej przestrzeni życiowej. Zadania stawiane przez współczesne społeczeństwo wymagają tworzenia i spełnienia jednostki, która uczy się żyć oraz może się rozwijać w wymiarze indywidualnym i zbiorowym poprzez profesjonalizację i wykorzystywanie własnego potencjału kompetencji. Współczesne zadania cywilizacyjne nie opierają się na przygotowaniu jednostek do zastanego społeczeństwa, ale na dostarczaniu bodźców pozwalających każdemu człowiekowi poprzez wykorzystanie jego potencjału kompetencji zrozumieć otaczający świat, kreować go, być jego rzeczywistym uczestnikiem i odbiorcą oraz czuć się za niego odpowiedzialnym w teraźniejszości i w przyszłości.
\end{abstract}

Słowa kluczowe:

człowiek, społeczeństwo, kompetencje, profesjonalizacja, rozwój jednostki

\section{Abstract}

A contemporary human being expands and uses their individual abilities to update, deepen and enrich the potential of knowledge, skills and com-

${ }^{1}$ Małgorzata Elżbieta Krawczyk-Blicharska, Instytut Pedagogiki, Uniwersytet Jana Kochanowskiego w Kielcach, Polska, e-mail: mkrawczyk@ujk.edu.pl, ORCID ID: https://orcid.org/00000002-7526-8306. 
petences in order to adapt to the changing social living space. The tasks imposed by the contemporary society necessitate creation and fulfillment of an individual who learns to live and is able to develop in the individual and collective dimension by professionalisation and use of their own competence potential. The contemporary civilisational tasks are not based on preparing individuals for the existing society but on providing stimuli enabling every human being, by using their competence potential, to understand the surrounding world, to create it, to be its actual participant and recipient, and to feel responsible for it now and in the future.

\section{Keywords:}

human, society, competences, professionalization, individual development

\section{WSTĘP}

Współczesny człowiek może poszerzać i wykorzystywać indywidualne możliwości do aktualizowania, pogłębiania oraz wzbogacania wiedzy, umiejętności i kompetencji, by przystosować się do zmieniającej się społecznej przestrzeni życiowej. Czynnikiem determinującym takie zachowania jest proces uczenia się przez całe życie. Edukacja oraz uczenie się staje się wielowymiarowym i długoterminowym procesem obejmującym zdobywanie wiedzy, kształtowanie postaw, wykorzystywanie umiejętności oraz profesjonalizację zasobów kompetencyjnych. Ponadto umożliwia znajdowanie celu i sensu życia oraz rozumienie siebie i innych w zmieniającym się świecie. Pomaga też pokonywać trudności i rozwiązywać problemy oraz realizować zadania i osiągać cele. Aby edukacja mogła spełnić misję działania całożyciowego, kształtującego potencjał kompetencyjny jednostek, istotne jest, by wyposażała je w zasoby do tego, aby wiedzieć, działać, uczestniczyć i rozwijać się w sposób indywidualny, zawodowy, społeczny, w teraźniejszości i przyszłości.

Całożyciowa edukacja zakłada odejście od wizji edukacji postrzeganej jako konieczna droga do osiągnięcia określonych rezultatów, a traktowanie jej funkcji w sposób integralny, jako tworzenia i spełnienia jednostki, która uczy się żyć w wymiarze indywidualnym i zbiorowym poprzez wykorzystywanie wysokiego poziomu indywidualnych kompetencji. Jej zadaniem będzie nie tyle przygotowanie jednostek do zastanego społeczeństwa, ale dostarczanie bodźców pozwalających zrozumieć otaczający świat, być jego rzeczywistym uczestnikiem i odbiorcą oraz czuć się za niego odpowiedzialnym i kształtować go, wykorzystując własne zasoby kompetencji. Nabywanie, doskonalenie i profesjonalizacja kompetencji da podstawę dla rozwoju jednostki w zmieniającej się przestrzeni społecznej. 
Wysokojakościowe kompetencje przyczynią się do kreacji człowieka, który będzie się zderzał z nowymi wyzwaniami, celami i zadaniami.

\section{KOMPETENCJE KLUCZOWE KSZTAŁTOWANE W PROCESIE UCZENIA SIĘ PRZEZ CAtE ŻYCIE}

Ponowoczesność i jej powiązania warunkują to, że każda jednostka będzie potrzebowała szerokiego spektrum kompetencji oraz będzie mogła rozwijać je nieprzerwanie, przez całe życie. Zdaniem D. Stępkowskiego kompetencji nie można posiąść raz na zawsze, tzn. bez potrzeby modyfikowania, a ponieważ są one ściśle powiązane z myśleniem refleksyjnym, trzeba się ich nieustannie uczyć - przez całe życie (Stępowski, 2018, s. 89).

Etymologia i pierwotne rozumienie kompetencji nawiązuje do potencjału podmiotu i jego zdolności do wykonania określonych typów działań. Inaczej oznacza przydatność i odpowiedzialność.

Potocznie kompetencje rozumiane są jako umiejętność życia wśród ludzi i współpracy z nimi oraz umiejętność rozwiązania problemów jednostkowych i zbiorowych. To zakresy umiejętności, które przyczyniają się do skutecznej interakcji z otoczeniem oraz warunkują adaptacyjność do nowych, zmieniających się warunków.

W rozumieniu uniwersalnym kompetencje - to udowodniona (w nauce, pracy oraz w rozwoju osobistym) zdolność samodzielnego stosowania posiadanych umiejętności z uwzględnieniem zinternalizowanego systemu wartości. Podłożem dla takiego rozumienia kompetencji jest odpowiedzialność i autonomia.

Globalny wymiar kompetencji wyznacza pełny zakres zachowań przygotowujących jednostki do skutecznego i konstruktywnego uczestnictwa we wspólnotowym życiu społecznym. Opiera się ono na współpracy, asertywności i kompromisie. Preferuje zdolności do konstruktywnego porozumiewania się w różnych środowiskach, wykazywania się tolerancją, wyrażania i rozumienia różnych punktów widzenia, negocjowania połączonego ze zdolnością tworzenia klimatu zaufania oraz zdolności do empatii, ponadto radzenia sobie z problemami, stresem i frustracją. Składnikiem globalnego wymiaru kompetencji są kompetencje kluczowe.

Kompetencje kluczowe to te, które są potrzebne jednostce do rozwoju i samorealizacji, efektywnego włączenia oraz funkcjonowania zawodowego i społecznego, zrównoważonego stylu życia i kierowania nim oraz aktywnego obywatelstwa w zróżnicowanej przestrzeni kulturowej. Cechą kompetencji kluczowych jest ich 
całożyciowość w takim oto rozumieniu, że powinny być kształtowane i rozwijane na skali całego życia.

Kompetencje całożyciowe odnoszą się do kilku obszarów, tj. informacji, wiedzy, rozumienia i uczenia się, obszaru komunikowania się i tworzenia relacji społecznych, obszaru matematyczno-cyfrowo-technologicznego, a także kreacji postaw przedsiębiorczych, społecznych i kulturowych.

Rekomendacje europejskie określają szczegółowe kompetencje, które opierają się na ośmiu komponentach niezbędnych do funkcjonowania człowieka we współczesnej, całożyciowej przestrzeni społecznej (Dziennik Urzędowy UE 2018/C 189/01, 2018).

Pierwszy komponent stanowi grupa kompetencji w zakresie rozumienia i tworzenia informacji. Obejmuje ona przede wszystkim zdolności i umiejętności identyfikowania, rozumienia, wyrażania, tworzenia i interpretowania pojęć, uczuć, faktów i opinii w mowie i piśmie, przy wykorzystaniu obrazów, dźwięków i materiałów cyfrowych we wszystkich dziedzinach i kontekstach. Zakłada ona zdolność skutecznego komunikowania się i porozumiewania się z innymi osobami, we właściwy i kreatywny sposób. Te kompetencje stanowią podstawę dalszego uczenia się i innych interakcji językowych.

Drugi to kompetencje w zakresie wielojęzyczności. Określają zdolność do prawidłowego i skutecznego korzystania z języków obcych w celu porozumiewania się. Obszar tych umiejętności obejmuje zdolności rozumienia, wyrażania i interpretowania pojęć, myśli, uczuć, faktów i opinii w mowie i piśmie w odpowiednim kontekście społecznym i kulturowym. Kompetencje językowe zawierają w sobie wymiar historyczny oraz kompetencje międzykulturowe. Opierają się na zdolności do pośredniczenia między różnymi językami i mediami oraz społeczeństwami.

Kolejny komponent obejmuje trzy obszary: kompetencje matematyczne, kompetencje w zakresie nauk przyrodniczych oraz technologii i inżynierii. Kompetencje matematyczne charakteryzuje zdolność rozwijania i wykorzystywania myślenia oraz postrzegania matematycznego do rozwiązywania problemów w codziennych sytuacjach. Kompetencje w zakresie nauk przyrodniczych dotyczą zdolności i chęci wyjaśniania świata przyrody z wykorzystaniem istniejącego zasobu wiedzy i stosowanych metod, w tym obserwacji i eksperymentów, w celu formułowania pytań i wyciągania wniosków opartych na dowodach. Kompetencje techniczne i inżynierskie obejmują stosowanie specjalistycznej wiedzy i metod w odpowiedzi na postrzeganie ludzkich potrzeb i wymagań w zakresie zmiany oraz znacząco przyczyniają się do postępu i rozwoju.

Czwarty komponent stanowią kompetencje cyfrowe. Obejmują one odpowiedzialne i krytyczne korzystanie z technologii cybernetycznych i przestrzeni 
wirtualnej do celów uczenia się, pracy i udziału w społeczeństwie. Ich składnikiem są umiejętności korzystania z informacji i danych elektronicznych, komunikowanie się i współpraca, umiejętność korzystania z mediów i multimediów, tworzenie treści cyfrowych, bezpieczeństwo (w tym cyberbezpieczeństwo), kwestie dotyczące własności intelektualnej, rozwiązywania problemów i krytycznego myślenia z wykorzystaniem narzędzi cyfrowych.

Kompetencje osobiste, społeczne i w zakresie umiejętności uczenia się stanowią komponent piąty. Są to zdolności do autorefleksji, automotywacji, skutecznego zarządzania czasem i informacjami, tworzenia relacji interpersonalnych, konstruktywnej pracy z innymi osobami, zachowania odporności oraz zarządzania własnym uczeniem się i karierą zawodową. Powyższe kompetencje opierają się na zdolności do określania i wyznaczania celów, motywowania siebie i innych, rozwijania odporności i pewności siebie, a także nastawieniu na rozwiązywanie problemów i pokonywanie przeszkód oraz radzenie sobie ze zmianami.

Komponent szósty obejmuje kompetencje obywatelskie, bazujące na zdolności do działania oraz pełnego uczestnictwa w życiu społecznym. Ich funkcjonalność opiera się na rozumieniu pojęć i struktur społecznych, gospodarczych, prawnych i politycznych, a także wydarzeń globalnych i zrównoważonego rozwoju. Fundamentem odpowiedzialnej i konstruktywnej postawy obywatelskiej jest poszanowanie praw człowieka jako podstawy demokracji.

Kolejnym szczegółowym składnikiem kompetencji kluczowych są kompetencje w zakresie przedsiębiorczości. Postawa przedsiębiorcza charakteryzuje się zmysłem inicjatywy i poczuciem sprawczości, proaktywnością, otwartością na przyszłość, odwagą i wytrwałością, a także przyjmowaniem odpowiedzialności i promowaniem postaw etycznych. Przedsiębiorczość opiera się na kreatywności, krytycznym myśleniu i rozwiązywaniu problemów, co więcej, podejmowaniu inicjatyw oraz wspólnym działaniu służącym tworzeniu projektów przedstawiających wartość kulturalną, społeczną lub finansową i zarządzaniu nimi.

Kompetencje w zakresie świadomości i ekspresji kulturalnej stanowią ostatni komponent kompetencji kluczowych. Obejmują rozumienie sposobów kreatywnego wyrażania i komunikowania pomysłów i ich znaczeń w różnych kulturach, za pomocą różnych rodzajów sztuki oraz innych form kulturalnych. Pokazują angażowanie w rozumienie, rozwijanie i wyrażanie własnych pomysłów oraz odczuwanie swojego miejsca lub roli w społeczeństwie na wiele różnych sposobów i w wielu kontekstach. Kompetencje te wymagają znajomości lokalnych, regionalnych, krajowych, europejskich i ogólnoświatowych kultur i sposobów ich ekspresji. Kluczowe znaczenie ma otwartość wobec różnorodności ekspresji kulturalnej i jej poszanowanie, wraz z etycznym i odpowiedzialnym podejściem 
do własności intelektualnej i kulturowej (Por. Dziennik Urzędowy UE 2018/C 189/01, 2018).

W procesie całożyciowego uczenia się dominują dwa ujęcia kompetencji. Pierwsze określa kompetencję jako adaptacyjny potencjał podmiotu, pozwalający mu na dostosowanie działania do warunków wyznaczanych przez charakter otoczenia, a jest ono tu traktowane jako rzeczywistość o statycznym w założeniu charakterze. Drugie przedstawia kompetencję jako transgresyjny potencjał podmiotu, gdzie generowane przez nią typy działań są podatne na twórczą modyfikację, następują w rezultacie interpretacji - w założeniu dynamicznego - kontekstu działania (Męczkowska, 2003, s. 693-696).

Transgresyjny wymiar kompetencji odpowiada podejściu strukturalistycznemu i oznacza, iż jest on zintegrowaną strukturą poznawczą, tkwiącą u podstaw zachowań pomiotu w zakresie regulacji relacji człowieka ze światem. Podkreśla się jego generatywny charakter niekiedy warunkowany biologicznymi dyspozycjami podmiotu do nabywania kompetencji. Proces budowania kompetencji jest nabywaniem i reorganizowaniem dotychczas posiadanych przez podmiot wzorców myślenia i działania. Wiedza i umiejętności zaś stają się narzędziami umożliwiającymi dalsze kreowanie przez podmiot indywidualnych struktur poznawczych oraz dyspozycji do działania (Męczkowska, 2003, s. 696).

Przedstawione ujęcia można odnieść do podziału dokonanego przez R. Kwaśnicę (1990) różnicującego kompetencje podmiotu na dwa typy: kompetencje realizacyjne i interpretacyjne. Pierwsze z nich odnoszą się do wiedzy natury technicznej oraz umiejętności posługiwania się określonymi środkami i metodami działania. Drugie zaś oznaczają samodzielne formułowanie celów działania przez podmiot, twórcze konstruowanie jego metod oraz analizę społecznego kontekstu działania - zastanych norm i warunków działania.

Reasumując, kompetencje kluczowe to umiejętności stanowiące podstawę dla kształtowania szeroko rozumianych kompetencji uniwersalnych pozwalających na „dawanie sobie rady” - tu i teraz, i za kilka lat (dawanie sobie rady w sytuacjach edukacyjnych, społecznych, zawodowych i rodzinnych). Komponenty pakietu kompetencji kluczowych uznaje się za jednakowo ważne i komplementarne. Każdy z nich przyczynia się do efektywnego życia jednostki i jej rozwoju. Takie kompetencje mogą być stosowane w wielu różnych kontekstach i rozmaitych kombinacjach. Ich zakresy pokrywają się i przenikają, są ze sobą powiązane. Korelacja takich kompetencji, jak krytyczne myślenie, rozwiązywanie problemów, umiejętności komunikacyjne, praca zespołowa, umiejętności cyfrowe i analityczne, kreatywność oraz umiejętności międzykulturowe są podstawą funkcjonowania i rozwoju jednostki w dzisiejszym społeczeństwie i globalnym świecie. 


\section{PAKIET KOMPETENCJI UNIWERSALNYCH W ROZWOJU JEDNOSTKI}

Dynamiczne zmiany, nowoczesne technologie, potencjał wiedzy, zakres informacji, selekcyjny rynek pracy oraz współczesne wyzwania społeczno-cywilizacyjne określają rolę człowieka oraz jego potencjału kompetencji w społeczeństwie. Obecnie każdy może/powinien zostać wyposażony w „paszport do życia” (Delors, 1998, s. 79) pozwalający na funkcjonowanie w ponowoczesnym świecie. Ważnym elementem składowym „paszportu do życia” są uniwersalne kompetencje człowieka, pozwalające na kształtowanie indywidualnej przestrzeni rozwojowej oraz bycie uczącym się, samodzielnie myślącym, motywującym się i działającym podmiotem życia społecznego.

Tym, co warunkuje i różnicuje potencjał kompetencji, jest proces ich nabywania. Koncepcja kompetencji osadzona w behawiorystycznej perspektywie ma charakter instrumentalny. Cechuje ją działanie ukierunkowane na ściśle zaplanowany cel, co wynika z przekonania, że każde posunięcie człowieka ma charakter sprawczy i jest instrumentem prowadzącym podmiot do kontroli nad zewnętrznym otoczeniem społeczno-przyrodniczym i jako takie podlega modelowaniu. W ten sposób relacja podmiotu ze światem ma charakter techniczny, polegający na stosowaniu wyćwiczonej umiejętności określonego typu, natomiast bycie kompetentnym oznacza bycie efektywnym, a kompetencja oznacza dyspozycję do instrumentalnego działania związaną z wiedzą, umiejętnościami, motywacją oraz przekonaniem podmiotu o posiadaniu owej dyspozycji. Jako adaptacyjny potencjał kompetencja podlega treningowi, którego celem jest osiągniecie przez podmiot założonego poziomu sprawności, gdyż rezultat wykonanego przez niego zadania będzie odpowiadał założonemu wzorcowi wykonania. Po osiągnięciu biegłości podmiotu w wykonaniu określonego działania koncepcja nie podlega już dalszej modyfikacji (Męczkowska, 2003, s. 694).

Kompetencję ujętą behawiorystycznie często sprowadza się ponadto do kompetencji zawodowej lub kompetencji profesjonalnej, pojmowanych jako zbiór kwalifikacji wyznaczających pozycję podmiotu na rynku pracy lub w strukturze organizacji pracy. Takie myślenie w kategoriach ekonomiczno-rynkowych dostrzegalne jest także w polityce edukacyjnej, gdzie podstawową kwestią staje się problem adaptacji pokolenia aplikującego do potrzeb rynku pracy, a poziomy kompetencji odnoszą się do kształtowania ekonomicznego kapitału ludzkiego. Ograniczenie edukacji do nabywania określonych i zamkniętych typów kompetencji prowadzi do hamowania niezależności myślenia i działania, a także stawia podmiot w relacji zależności (Męczkowska, 2003, s. 695). 
Ponowoczesność stawia wyzwania wobec jednostki i jej kompetencji. Proces nabywania i doskonalenia kompetencji nie ma charakteru procesu zamkniętego, tylko jest mobilny i permanentny. Wysokie i wielorakie kompetencje oraz ich dynamika wzrostu są kluczowymi czynnikami sprzyjającymi rozwojowi każdego aktywnego człowieka. Czynnikiem zapewniającym rozwój jednostki jest posiadanie uniwersalnego pakietu kompetencji składającego się z czterech kategorii, tj. kompetencji osobistych, społecznych zawodowych i menedżerskich.

Kompetencje osobiste są związane z indywidualnym sposobem realizacji zadań. Poziom tych kompetencji wpływa na ogólną jakość wykonywanych zadań - decyduje o szybkości, jakości i zaangażowaniu w podejmowane działania.

Kompetencje społeczne wpływają na sposób budowania i jakość relacji z innymi oraz sposób wykonywania zadań związanych z takimi kontaktami. Poziom tych kompetencji decyduje o skuteczności współpracy, porozumiewania się i wywierania wpływu na innych.

Kompetencje zawodowe są kompetencjami mającymi związek ze specjalistycznymi zadaniami dla danej grupy zawodowej. Często odnoszą się do zakresów konkretnej wiedzy (np. prawniczej czy też finansowej) lub umiejętności (np. obsługa określonych systemów IT). Poziom tych kompetencji wpływa na efektywność realizacji zadań związanych ze specyfiką zawodu, stanowiska bądź funkcji.

Kompetencje menedżerskie i przywódcze są związane z zarządzaniem zasobami ludzkimi i organizacjami. Dotyczą zarówno miękkich obszarów kierowania, organizacji pracy, jak i strategicznych aspektów zarządzania. Poziom tych kompetencji decyduje o skuteczności kierowania organizacją i jej kapitałem osobowym i materialnym (Uniwersalny model kompetencyjny, s. 18-19).

Pierwszą część kompetencji uniwersalnych stanowi pakiet kompetencji osobistych i społecznych. Kompetencje osobiste dotyczą szeroko rozumianej samowiedzy oraz umiejętności zarządzania sobą. Odgrywają istotną rolę w odkrywaniu jednostkowego potencjału, doskonaleniu go, a następnie jego pełnym wykorzystaniu. Kompetencje te są kluczowym czynnikiem samorealizacji jednostki oraz pomagają jej w zrozumieniu siebie i swojej drogi życiowej. Natomiast kompetencje społeczne określają zdolności obcowania z innymi, świadomość społeczną oraz zarządzania relacjami i otoczeniem. Świadomość społeczną można określić jako system powiązań tworzących i organizujących życie społeczne, składające się z wyobrażeń rzeczywistości. Zasadniczo dotyczy ona sposobów myślenia, a więc wartości społecznych, konwenansów, opinii, poglądów i postaw ludzi. Ponadto uwzględnia wrażliwość społeczną, style i formy komunikacyjne, obyczajowość, estetykę, religię, politykę, etykę itp. Wyobrażenia te, połączone z ich świadomością i wrażliwością, tworzą bardzo różnorodną sieć porozumienia 
między poszczególnymi członkami danego społeczeństwa. Im wyższa świadomość społeczna, tym sprzężenia zwrotne między ich członkami silniejsze i trwalsze. (Karwala, 2009, s. 62, 64).

Drugą część uniwersalnego pakietu kompetencyjnego stanowią kompetencje prorynkowe - zawodowe i menedżerskie. Głównym składnikiem pakietu kompetencji prorynkowych są kompetencje twarde i miękkie. Twarde traktowane są jako zasoby oparte o posiadane kwalifikacje zawodowe. Miękkie natomiast podkreślają znaczenie komunikacji, motywacji, a także przywództwa. Przywództwo najczęściej opiera się na procesie oddziaływania na innych ludzi. Kompetencje menedżerskie nie są tylko ukierunkowywane na koordynowanie działań, ale ich właściwością jest również budowanie cech osobowościowych jednostki, która takie oddziaływania stosuje.

Przemiany cywilizacyjno-kulturowe, a także trend ciągłej zmiany technologicznej zachodzącej w środowisku pracy, przyczyniać się będą do potrzeby formatowania kompetencji menedżerskich, które pozwolą na nowe odkrycie i zrozumienie zasobów, potrzeb, problemów i możliwości rynku pracy, a także na modyfikowanie zarządzania pracą oraz kapitałem ludzkim w wymiarze nieznanym dotychczas.

Obraz kompetencji menedżerskich prezentują badania dotyczące kompetencji kadry zarządzającej. Wyłania się z nich obraz dzisiejszego menedżera pracującego w organizacjach, w których liczą się: umiejętność priorytetyzacji i podejmowania decyzji, konsekwencja w realizacji celów i monitorowanie wykonywania zadań. Mniej istotne są: współpraca międzykulturowa, empatia i zarządzanie emocjami.

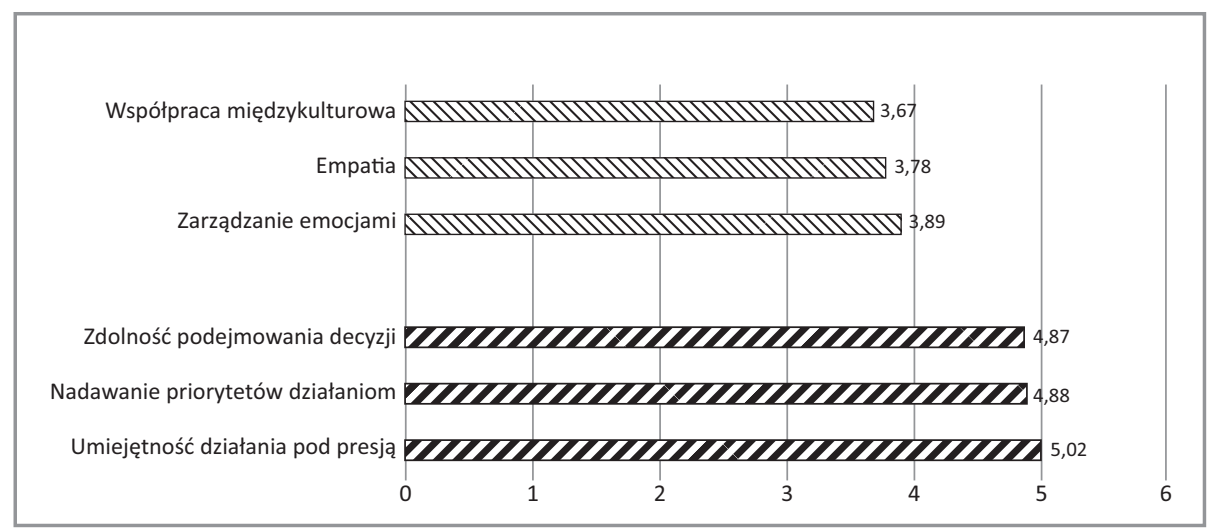

Wykres 1. Kompetencje menedżera oceniane najniżej i najwyżej na rynku pracy Źródło: badania GFKM, Magazyn Forbes, 2019 r. 
Skrajne oceny kompetencji zadaniowych i tych związanych z ludzką emocjonalnością zaskakują. Niemniej jednak wpływ na to może mieć profil zarządzania preferowany w większości firm na polskim rynku. Zdaniem T. Harackiewicza nadal znaczna część firm zarządzana jest w oparciu o wielopoziomowe hierarchie. Prezes wymaga od dyrektora, dyrektor od kierownika, kierownik wywiera presję na pracownika. Występuje niewystarczający poziom dialogu, współodpowiedzialności i współpracy budowanej na wzajemnym zaufaniu. Niestety takiego podejścia uczy się już na wczesnym i kolejnych poziomach edukacji. W wymiarze rynkowym za mało docenia się wagę inteligencji emocjonalnej w procesie efektywnego realizowania zadań (Magazyn Forbes, badania GFKM, 2019).

Na uwagę zasługują wskazania uzyskane w odpowiedzi na pytanie o kompetencje pożądane w przyszłości. Badani uznali, że najmniej istotną kompetencją będzie empatia. Jeszcze bardziej niepokojące jest to, że na końcowych pozycjach znalazły się szczerość i otwartość w kontakcie z pracownikami. Według T. Harackiewicza (2019) można z tego wnioskować, iż polscy menedżerowie nie widzą niczego nagannego w niemówieniu wszystkiego, a w skrajnych przypadkach nawet w okłamywaniu pracowników, jeśli tylko realizowane są zadania i osiągane zakładane cele. Powyższe dane obrazują niepokojące zjawisko szczególnie, gdy przeanalizuje się ocenę znaczenia kompetencji w zakresie wysokich standardów moralnych i etycznych - znalazły się one na dalekim, 29. miejscu w ocenie badanych.

Inaczej wyglądają wyniki światowych badań na temat kompetencji kadry zarządzającej. Badania przeprowadzone przez S. Giles, prezeskę Quantum Leadership Group, na grupie 195 liderów z 15 krajów i ponad 30 globalnych organizacji, wykazały, że wysoki poziom etyczny i moralny menedżera jest najważniejszy (wśród 72 ocenianych kompetencji) dla aż 67\% biorących udział w badaniu (2019).

Pracownicy najczęściej oczekują od menedżerów-liderów umiejętności stwarzania warunków do otwartego mówienia o problemach i wspierania w ich rozwiązaniu, a także częstego i otwartego komunikowania się oraz opierania się na faktach, a nie na opiniach. Różnice w oczekiwaniach pracowników i podejściu menedżerów do kompetencji są widoczne również w badaniu GFKM. Większy wzrost oczekiwań co do zarządzania emocjami odnotowano u badanych pracujących na stanowiskach specjalistycznych. Wyższą rangę do kompetencji związanych z emocjami przykładali menedżerowie firm z udziałem kapitału zagranicznego, osoby poniżej 30. roku życia oraz kobiety.

W rankingu kompetencji (opracowanym w badaniu GFKM), które będą ważne w przyszłości, dominują te dotyczące przystosowywania się do zmieniającej się rzeczywistości. Do najważniejszych zaliczono: szybkie reagowanie na zmiany, gotowość do ciągłego uczenia się oraz otwartość na nowe pomysły i działania. 


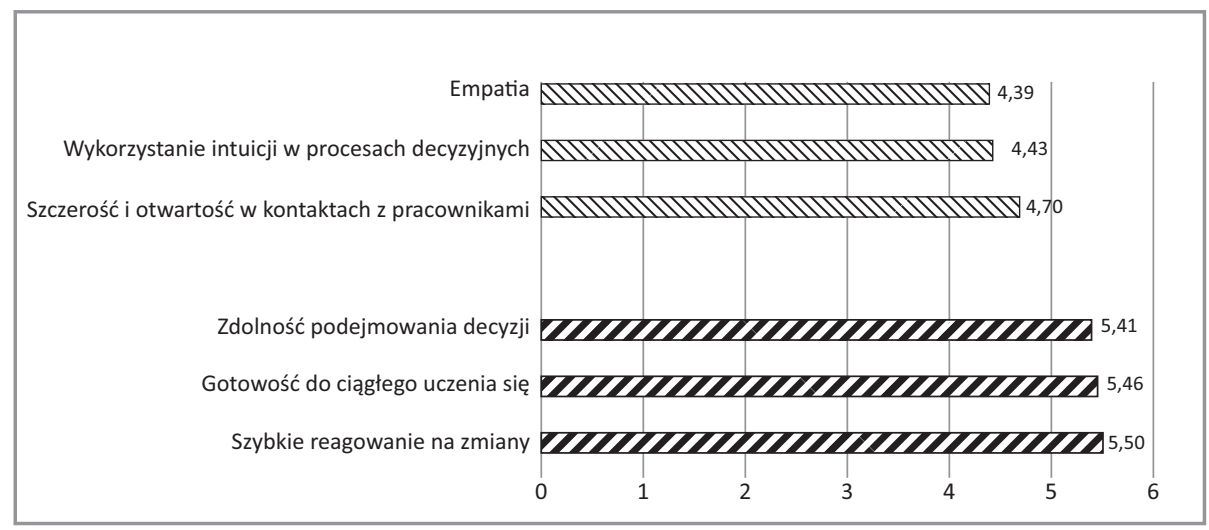

Wykres 2. Kompetencje przyszłości oceniane najniżej i najwyżej na rynku pracy Źródło: badania GFKM, Magazyn Forbes, 2019 r.

W pierwszej dziesiątce znalazły się też: aktywne poszukiwanie nowej wiedzy i elastyczność w działaniu. Niepewność dotycząca przyszłości i permanentna zmiana towarzysząca uwarunkowaniom rynkowym wskazuje za istotne kompetencje: gotowość do uczenia się oraz otwartość na nowe pomysły i działania. Ta ostatnia kompetencja w opinii badanych zmieniła miejsce z 23 obecnie na 3 w przyszłość.

W warunkach pandemii rynek pracy promuje procesy automatyzacji i platformizacji. W nich głównie odnajdą się tacy pracownicy, którzy bazując na zaawansowanych kompetencjach poznawczych, społecznych i technicznych (w tym cyfrowych) będą potrafili dostosowywać profil swoich umiejętności do szybko zmieniających się oczekiwań pracodawców. Kluczowego znaczenia nabierają kompetencje, które odróżniają pracę człowieka od pracy systemów informatycznych, robotów czy sztucznej inteligencji. Ponieważ w tych obszarach człowiek będzie wciąż trudny do zastąpienia, zostały one nazywane kompetencjami przyszłości. Zalicza się do nich:

Kompetencje poznawcze - potocznie nazywane kompetencjami myślenia. Jest to pojęcie bardzo szerokie, obejmujące zarówno kreatywność, jak i logiczne rozumowanie i rozwiązywanie złożonych problemów.

Kompetencje społeczne - są niezbędne w środowisku pracy, które wymaga kontaktu z drugim człowiekiem, pracy zespołowej lub zarządzania ludźmi. Należą do nich: efektywna współpraca w grupie, przywództwo i przedsiębiorczość oraz inteligencja emocjonalna.

Kompetencje cyfrowe i techniczne - to umiejętności tzw. twarde. Szczególnie ważne są kompetencje cyfrowe, które nabierają podstawowego znaczenia. Nie 
ograniczają się jedynie do programowania czy analizy danych, ale obejmują szeroki zakres umiejętności od cyfrowego rozwiązywania problemów po wiedzę z zakresu prywatności czy cyberbezpieczeństwa (por. Włoch, Śledziewska 2019, s. 10).

Kompetencje przyszłości stają się elementem dopełniającym uniwersalny pakiet kompetencyjny. Wtedy można uznać go jako koherentny, funkcjonalny, wykorzystywany w praktyce (społecznej i zawodowej) oraz uwarunkowany osobowościowo, zestaw wiedzy, zdolności, umiejętności, postaw oraz doświadczeń. Pakiet ten umożliwia jednostce podejmowanie i rozwijanie twórczych relacji z innymi osobami, aktywne współuczestniczenie w życiu grup społecznych, skuteczne pełnienie ról społeczno-zawodowych oraz twórcze realizowanie zadań i efektywne rozwiązywanie pojawiających się problemów. Taki zestaw kompetencji jest niezbędny z punktu widzenia samorealizacji i odnalezienia się we współczesnym uczącym się społeczeństwie i zmieniającym się rynku pracy. Stanowią też podłoże do świadomego oraz ukierunkowanego na przyszłość rozwoju jednostki w zmieniającym się świecie.

\section{BUDOWANIE POTENCJAŁU KOMPETENCJI I JEGO PROFESJONALIZACJA}

Społeczeństwo ponowoczesne tworzy warunki dla aktywnego człowieka, posiadającego odpowiednie wykształcenie i cechy przedsiębiorcy, charakteryzującego się mobilnością działaniową i myślową, umiejącego porozumiewać się i współdziałać z innymi członkami społeczeństwa, mającego świadomość ważności nabywania oraz ulepszania poziomu i zestawu własnych kompetencji.

Możliwość zdobycia wysokich kwalifikacji w realny sposób przyczynia się do podwyższenia poziomu wykształcenia ogółu społeczeństwa oraz do pełnej samorealizacji jednostek. Natomiast kompetencje warunkują pełną możliwość adaptacji w różnych sytuacjach społecznych oraz przyczyniają się do optymalizacji efektywności działań indywidualnych i zbiorowych. Tworzą nowy wymiar i nowe możliwości w dostosowaniu człowieka do życia w ponowoczesnym społeczeństwie.

Proces nabywania kompetencji należy rozpatrywać z perspektywy ich kompozycji. Kompetencje tworzą harmonijny konstrukt wiedzy, rozumienia, sprawności oraz pragnienia. Wymienione cztery składowe kompetencji można odczytywać w przestrzeni dynamicznej i statycznej. Kluczową jest dyspozycja dynamiczna, ponieważ odnosi się do przebiegu procesu nabywania kompetencji, obejmującego co najmniej cztery etapy: nauczanie-uczenie się, ćwiczenie-doskonalenie, interpretowanie i dążenie. $\mathrm{W}$ procesie nabywania kompetencji kluczowe miejsce zajmuje 
człowiek poprzez aktywizowanie sowich sfer - kognitywnej przez pragmatyczną, aż do emocjonalnej. Analiza pojęcia kompetencji od strony tych sfer tworzy statyczny sposób jego odczytania (Stępowski, 2018, s. 89).

Indywidualny potencjał kompetencyjny każdego człowieka powinno budować się poprzez świadome, zamierzone i celowe przechodzenie określonych etapów i systematyczne doskonalenie określonej sprawności. Planowe nabywanie i utrwalanie kompetencji pozwoli na efektywne posługiwanie się nimi i gwarantuje poprawne budowanie jednostkowej ścieżki rozwoju. Potencjał nabywania, utrwalania i wykorzystania kompetencji umożliwia efektywny rozwój, natomiast ich brak może spowodować blokadę lub barierę, utrudniającą albo uniemożliwiającą adaptację i rozwój w obecnym świecie.

Etapy budowania kompetencji obejmują ich cztery zakresy. Nieświadoma niekompetencja - jednostka nie zdaje sobie sprawy z tego, że pod jakimś względem brakuje jej kompetencji. Świadoma niekompetencja - jednostka zaczyna dostrzegać posiadane deficyty kompetencyjne i rozpoczyna ich kompensacje. Świadoma kompetencja - jednostka wie, że jest w stanie wykonać określone zadanie, ale wykonanie go wymaga od niej maksymalnego skupienia i wysiłku. Na tym etapie widać już pierwsze postępy w posługiwaniu się daną umiejętnością. Nieświadoma kompetencja - charakteryzuje wysoki poziom wiedzy, doświadczenia i sprawności w posługiwaniu się daną umiejętnością. Zadania na tym etapie wykonywane są automatycznie, z dużą perfekcją i nie wymagają ciągłej samomotywacji i samokontroli. (Wilczyńska, Nowak, Kućka, Sawicka, Sztajerwald, 2013, s. 144-145; por. Szempruch, 2013, s. 112).

Charakter procesu kształtowania kompetencji powinien mieć wymiar celowy i świadomy. W procesie modelowania sprawności posługiwania się kompetencjami można wyróżnić kilka faz:

- symultaniczna ocena posiadanych kompetencji,

- diagnoza posiadanych kompetencji, określenie pożądanych kompetencji,

- identyfikacja i określenie luki kompetencyjnej,

- zbudowanie modelu kompetencji,

- określenie luk kompetencji (luki postrzeganej i luki modelowej),

- działania związane z niwelowaniem luki kompetencyjnej,

- ewaluacja realizacji działań związanych z niwelowaniem deficytów kompetencyjnych (Rakowska, 2007, s. 145-147).

W procesie kształtowania kompetencji zachodzi synergia, którą można uzyskać poprzez jednoczesne doskonalenie składowych elementów kompetencji: wiedza, umiejętności, postawy i wartości oraz osobowość - odnosząca się do procesów ich doskonalenia (Rakowska, 2007, s. 147-148). 
Rozwój kompetencji jest związany z koniecznością dokładnego określenia możliwości rozwoju, determinacji do zmiany oraz znalezienia sposobów, które będą mu sprzyjać. Czynnik motywacyjny jest szczególnie istotny; bez odpowiedniej woli jakikolwiek rozwój jest utrudniony, a czasem wręcz niemożliwy. Rozwoju kompetencji może dokonać tylko ta jednostka, u której występuje jej deficyt. Poszerzanie kompetencji nie jest możliwe bez zaangażowania i działania danej jednostki. Rozwój kompetencji jest procesem permanentnym. Rozwijając daną kompetencję, stopniowo dokonuje się przejścia na coraz wyższy jej poziom. Natomiast wielość i różnorodność kompetencji powoduje, że przyjmuje się pięciostopniową skalę ich opanowania, tj.:

- brak przyswojenia wybranej kompetencji i zachowań wskazujących na jej opanowanie oraz wykorzystywanie w podejmowanych czynnościach i działaniach,

- kompetencja przyswojona w stopniu podstawowym, wykorzystywana nieregularnie; wymagane jest wsparcie oraz nadzór ze strony osób z większym doświadczeniem,

- kompetencja przyswojona w stopniu dobrym, pozwalająca na samodzielne posługiwanie się nią podczas wykonywania czynności i zadań zawodowych,

- kompetencja opanowana w stopniu bardzo dobrym, umożliwia bardzo dobrą realizację zadań oraz przekazywanie własnych doświadczeń innym podmiotom,

- kompetencja nabyta w stopniu doskonałym, zdolność do twórczego wykorzystywania i rozwijania wiedzy, umiejętności i postaw właściwych dla danego zakresu działań (Filipowicz, 2004, s. 23).

Większy zakres kompetencji i lepsza sprawność jego opanowania, a następnie wykorzystywania stwarza nieograniczone pola działaniowe, realizacyjne i samorealizacyjne dla jednostki. Nabywanie, doskonalenie i rozwijanie kompetencji staje się działaniem określającym zakres i wysoką sprawność w posługiwaniu się nimi oraz staje się elementem ich profesjonalizacji.

Termin „profesjonalizm” łączy się etymologicznie ze słowem „profesja”, inaczej zawód. Dziś termin ten ciągle ewoluuje, poszerza swoje znaczenie, obejmuje zdolności do odnajdywania się w coraz to nowych rolach. W takim rozumieniu człowiek profesjonalny to taki, który potrafi elastycznie dostosowywać się do pojawiających się sytuacji bez utraty kierunku, jaki sobie obrał w życiu, i zachowywać niezależność indywidualną, społeczną i ekonomiczną. Gotów jest podejmować nowe wyzwania, aktualizować i rozszerzać swoją wiedzę i umiejętności, wykorzystywać w sposób efektywny własne kompetencje i charakteryzować się dużą mobilnością i autonomią (por. Kaliszewska, Klasińska, 2018, s. 56). 
Podstawową cecha profesjonalizmu jest zbiór umiejętności pozwalających na samodzielne rozwiązywanie trudnych i złożonych problemów w danej dziedzinie, mających często charakter zadań eksperckich. Umiejętności te są efektem wykształcenia wyższego, uzupełnianego i korygowanego drogą ciągłego samokształcenia i praktyką zawodową. Ponadto profesjonalistę cechuje określona postawa wobec własnej pracy wynikająca z uznania prakseologicznych, moralnych i obyczajowych wzorów kulturowych profesjonalizmu. Wzory te służą przede wszystkim ochronie zawodu, oznaczeniu dystansu między profesjonalnym a amatorskim podejściem do wykonywania określonych zadań (Sikorski, 2007, s. 44, 46).

Współcześnie profesjonalizm utożsamiany jest z umiejętnością wykorzystania w praktyce wiedzy z danej dziedziny bądź zakresu, a za profesjonalistę uważana jest osoba stosująca abstrakcyjną wiedzę oraz kombinację różnych rodzajów wiedzy do rozwiązywania konkretnych problemów lub realizacji określonych zadań i działań. Takie sprawności i możliwość ich modelowania powinny być reprezentowane przez jednostkę na wysokim poziomie i pozyskane poprzez systematyczne ich uczenie się, trenowanie i wykorzystywanie w ciągu całego życia.

Przyjmuje się, że ludzie mają prawo i zadanie nabywania, doskonalenia i utrzymywania wysokich poziomów i zakresów kompetencji. Pozwala im to na rozwijanie się poprzez pełne uczestnictwo w życiu społeczeństw i skuteczne radzenie sobie ze zmianami na rynku pracy oraz na kreowanie wyzwań i generowanie profesjonalnych rozwiązań.

\section{ZAKOŃCZENIE}

Rozwój jednostki uzależniony jest od optymalizowania jej zasobów kompetencyjnych. Budowanie kompetencji w procesie całożyciowego uczenia się wymaga świadomości, w jaki sposób zidentyfikować i rozwijać zasoby potrzebne człowiekowi w dążeniu do samorealizacji, uczestnictwa w swobodnym kształtowaniu jego aktywnego życia oraz w ewolucji społeczeństwa. Wskazanym jest, by współczesne systemy edukacji i procesy kształcenia zaopatrywały wszystkich obywateli w nowe kompetencje oraz dawały możliwości do ciągłego rozwijania ich w procesie doskonalenia i profesjonalizacji oraz zapobiegały ich dezaktualizacji i deficytom.

Idea uczenia się przez całe życie wyznacza pewne kanony adaptacyjne i przyszłościowe dla rozwoju kompetencji jednostki. Chodzi o to, aby ludzie mieli większe zdolności dostosowawcze, cechowali się wyższym poziomem świadomości, odpowiedzialności, motywacji i satysfakcji oraz sprawnością wykorzystywania zasobów kompetencyjnych do tworzenia siebie w ewaluujących społeczeństwach. 
Ogromnego znaczenia nabierają kompetencje, które umożliwiają skuteczne i innowacyjne wykorzystywanie specjalistycznej wiedzy oraz umiejętności zawodowych w otoczeniu nacechowanym silną presją wyników, czasu, oczekiwań i działań konkurencyjnych. Ponadto otoczeniu wymagającym i złożonym, gdzie konieczna jest współpraca wielu osób - praca zespołowa, w którym trzeba chcieć i potrafić porozumieć się z innymi uczestnikami przestrzeni społecznej, często zróżnicowanej kulturowo, wreszcie otoczeniu, które umożliwia jednostce dużą wolność w zakresie autokreacji i samorealizacji, ale pozostawia ją osamotnioną, co powoduje, że kluczowego znaczenia nabierają odpowiedzialność za własny rozwój, zdolność odnalezienia się w życiu oraz samodzielność w zakresie zarządzania własnym życiem.

\section{Bibliografia}

Delors, J. (1998). Edukacja - jest w niej ukryty skarb. Raport Międzynarodowej Komisji do Spraw Edukacji dla XXI wieku. Warszawa: Wydawnictwo Stowarzyszenie Oświatowców Polskich.

Dziennik Urzędowy Unii Europejskiej (2018/C 189/01). (2018). Zalecenie Rady Unii Europejskiej z dnia 22 maja $2018 \mathrm{r}$. w sprawie kompetencji kluczowych w procesie uczenia się przez całe życie. Załącznik: Kompetencje kluczowe w procesie uczenia się przez całe życie - Europejskie ramy odniesienia. Bruksela.

Filipowicz, G. (2004). Zarzadzanie kompetencjami zawodowymi. Warszawa: Polskie Wydawnictwo Ekonomiczne.

Kaliszewska, M., Klasińska. B. (2018). Kompetencje hermeneutyczne w teorii i praktyce akademickiej. Kielce: Wydawnictwo Uniwersytetu Jana Kochanowskiego w Kielcach.

Karwala, S. (2009). Monitoring jako strategia wspierajq̨ca wszechstronny rozwój osobisty. Nowy Sącz: Wydawnictwo Wyższa Szkoła Biznesu-National Luis University.

Kwaśnica, R. (1990). Ku pytaniom o psychopedagogiczne kształcenie nauczycieli. W: Z. Kwieciński, L. Witkowski (red.), Ku pedagogii pogranicza. Toruń: Wydawnictwo Uniwersytetu Mikołaja Kopernika w Toruniu.

Magazyn Forbes (2019). Nieczuły jak szef? Niepokojq̨ce wyniki badań polskich menedżerów. Pobrane z: https://www.forbes.pl/kariera/nieczuly-jak-szef-badania-polskichmenedzerow-gfkm/6etqtx1?utm_source=www.forbes.pl_viasg_forbes\&utm_mediu$\mathrm{m}=$ referal\&utm_campaign=leo_automatic\&srcc=ucs\&utm_v=2.

Męczkowska, A. (2003). Kompetencja. W: T. Pilch (red.), Encyklopedia Pedagogiczna XXI Wieku (s. 693-696), t. 2. Warszawa: Wydawnictwo Akademickie „Żak”.

Rakowska, A. (2007). Kompetencje menadżerskie kadry kierowniczej we współczesnych organizacjach. Lublin: Wydawnictwo Uniwersytetu Marii Curie-Skłodowskiej.

Sikorski, C. (2007). Drogi do sukcesu. Profesjonalizm konta populistyczna kultura organizacyjna. Warszawa: Wydawnictwo Difin.

Stępkowski, D. (2018). Ogólna kompetencja pedagogiczna. W poszukiwaniu specyfiki 
kształcenia ogólnopedagogicznego. Rozważania teoretyczne i raport z badań. Kultura i Wychowanie. Półrocznik Pedagogiczny, 13.

Szempruch, J. (2013). Pedeutologia. Studium teoretyczno-empiryczne. Kraków: Wydawnictwo Impuls.

Uniwersalny model kompetencyjny. Podręcznik użytkownika. Podręcznik przygotowany przez Fundację Obserwatorium Zarzq̨dzania przy współpracy z Competency Institute (2017). Warszawa: Wydawnictwo Fundacja Obserwatorium Zarządzania. Pobrane z: https://docplayer.pl/1816641-Uniwersalny-model-kompetencyjny.html.

Wilczyńska, M., Nowak, M., Kućka, J., Sawicka, J., Sztajerwald, K. (2013). Moc coachingu. Poznaj narzędzia rozwijajq̨ce umiejętności i kompetencje osobiste. Gliwice: Wydawnictwo Helion.

Włoch, R., Śledziewska, K. (2019). Raport. Kompetencje przyszłości. Jak je kształtować w elastycznym ekosystemie edukacyjnym? Warszawa: Wydawnictwo: PFR, DELab UW. 